\title{
Tranilast Suppresses Intimal Hyperplasia in the Balloon Injury Model and Cuff Treatment Model in Rabbits
}

\author{
Juichi Fukuyama ${ }^{1}$, Kiyoshi Ichikawa ${ }^{1, *}$, Keiji Miyazawa ${ }^{1}$, Shuichiro Hamano ${ }^{1}$, Nobuo Shibata ${ }^{2}$ and Arao Ujiie ${ }^{1}$ \\ ${ }^{1}$ Pharmacological Laboratories and ${ }^{2}$ Second Laboratories, Kissei Pharmaceutical Co., Ltd., Hotaka, Nagano 399-83, Japan \\ Received August 28, 1995 Accepted January 25, 1996
}

\begin{abstract}
Intimal hyperplasia is a serious problem after percutaneous transluminal coronary angioplasty (PTCA). In this study, we investigated the effects of tranilast on intimal hyperplasia in both in vivo and in vitro experiments. For the in vivo experiments, we used the balloon injury model and the cuff treatment model of rabbits fed regular chow. In the balloon injury model, tranilast decreased intimal area, intima/media ratio, stenosis ratio and vascular DNA content after endothelial injury. Also in the cuff treatment model, tranilast suppressed the intimal hyperplasia. In the in vitro experiments, we assessed the effects of tranilast on platelet-derived growth factor-induced rabbit vascular smooth muscle cell (VSMC) migration and proliferation and on collagen synthesis by VSMCs. Tranilast inhibited VSMC migration, proliferation and collagen synthesis. These results suggest that tranilast has a suppressive effect on intimal hyperplasia after a vascular injury such as PTCA.
\end{abstract}

Keywords: Tranilast, Intimal hyperplasia, Balloon injury, Cuff treatment, Vascular smooth muscle cell

Percutaneous transluminal coronary angioplasty (PTCA) is one of the widely used therapies for patients with ischemic coronary artery disease. Although PTCA is successful, $30-50 \%$ of patients suffer from vascular restenosis within 6 months after the operation (1). The restenosis results from vascular smooth muscle cell (VSMC) migration from the media to the intima, where cells proliferate and cause on excessive accumulation of extracellular matrix produced by themselves $(2-4)$. The precise mechanism of the restenosis is unknown; however, it is reported that some cytokines, such as platelet-derived growth factor (PDGF), are implicated in the development of the restenosis $(4-6)$.

Tranilast is used for not only the patients with bronchial athma and allergic rhinitis but also those with proliferative diseases such as keloid and hypertrophic scars. Tranilast is reported to inhibit the release of chemical mediators and cytokines from various cells $(7-9)$ and the accumulation of collagen $(10-12)$. On the other hand, it is reported that an angiotensin II (Ang II) takes part in intimal hyperplasia (13-15) and that angiotensinconverting enzyme inhibitor or Ang II-receptor antagonist prevents the intimal hyperplasia (16-19).

In this study, we investigated the effects of tranilast and

\footnotetext{
* To whom correspondence should be addressed.
}

losartan, an Ang II-receptor antagonist, on the intimal hyperplasia in the balloon injury model and the cuff treatment model in rabbits fed regular chow. Moreover, to investigate the mechanisms involved, we assessed the effect of tranilast on PDGF-induced VSMC migration and proliferation and collagen synthesis.

\section{MATERIALS AND METHODS}

\section{Materials}

Tranilast, $N$-(3,4-dimethoxycinnamoyl) anthranilic acid and losartan (Dup 753) were synthesized in our laboratories. Fetal bovine serum (FBS) was purchased from Gibco Laboratories (Grand Island, NY, USA). Human recombinant PDGF-BB was purchased from R\&D System, Inc. (Minneapolis, MN, USA). ${ }^{3} \mathrm{H}$-Thymidine, ${ }^{3} \mathrm{H}$-proline and ${ }^{3} \mathrm{H}$-leucine were obtained from Du PontNEN (Boston, MA, USA). DNA dye (Hoechst 33258) was purchased from Eastman Kodak Company (Rochester, NY, USA).

\section{Animal}

Japanese White male rabbits (body weight: approx. 3 $\mathrm{kg}$ ) obtained from Keari Co., Ltd. (Osaka) were used. The rabbits were housed individually from 1 week before the experiment in a temperature $\left(23 \pm 2{ }^{\circ} \mathrm{C}\right)$-humidity 
$(55 \pm 5 \%)$ controlled room and were fed regular chow throughout the experimental periods.

\section{Balloon injury model}

Rabbits were anesthetized with $30 \mathrm{mg} / \mathrm{kg}$, i.v. sodium pentobarbital. Bilateral common carotid arteries were exposed and dissected from the surrounding tissues. An arterial embolectomy catheter (model 2F; Baxter Healthcare Corporation, Santa Ana, CA, USA) was inserted about $5 \mathrm{~cm}$ into the right common carotid artery through an incision made on the wall of the vessel. The balloon was inflated with the pressure of $1200 \mathrm{mmHg}$, and the intraluminal surface of the artery was rubbed by pulling back the balloon. After rubbing, the embolectomy catheter was pulled out from the vessel, and the incision on the wall of vessel was sutured. The left common carotid artery was used for a sham-operation. Four weeks after injury, the rabbits were sacrificed by exsanguination under anesthesia. Right and left common carotid arteries were removed, and each were cut into two segments. One segment was fixed in a $10 \%$ neutral solution of formaldehyde for morphometric analysis, and the other was frozen at $-40^{\circ} \mathrm{C}$ for later measurement of DNA content.

\section{Cuff treatment model}

Rabbits were anesthetized and bilateral common carotid arteries were exposed as described above. The right common carotid artery was sheathed with a cuff (length: $2 \mathrm{~cm}$, inner diameter: $2.38 \mathrm{~mm}$, outer diameter: $3.96 \mathrm{~mm}$ ) made of a polyethylene tube (TYGON ${ }^{(}$, R3603; Norton KK, Tokyo). The cuff was ligated with a silk thread according to the method described by Hirosumi et al. (20). The left common carotid artery was used for a sham-operation. Three weeks later, the rabbits were sacrificed by exsanguination under anesthesia, and then the bilateral common carotid arteries were removed. These arteries were fixed in a $10 \%$ neutral solution of formaldehyde for morphometric analysis.

\section{Morphometric analysis}

Transverse-cut specimens of fixed vessels were embedded in paraffin, and cross sections were cut from these blocks. The sections were stained by the Elastica-Van Gieson method. The intimal, medial and luminal area were measured with a morphometric analyzer (Lusex III; Nikon, Tokyo). Results were given as the intimal area, intima/media (I/M) ratio and stenosis ratio. The stenosis ratio was calculated as follows:

Stenosis ratio $(\%)$

$=($ intimal area $\times 100) /($ intimal + luminal area $)$

\section{DNA content}

DNA content was measured by a fluorometric assay as described by Labarca and Paigen (21). In brief, a 5-mm length of vessel was homogenized in phosphate-buffered saline ( $50 \mathrm{mM} \mathrm{Na} 2 \mathrm{PO}_{4}, 0.2 \mathrm{M} \mathrm{NaCl}, \mathrm{pH}=7.4$ ) and centrifuged at $3,000 \mathrm{rpm}$ for $5 \mathrm{~min}$. DNA dye (Hoechst 33258 ) was added to the supernatant at the final concentration of $1 \mu \mathrm{g} / \mathrm{ml}$. The resulting fluorescence was measured at $458 \mathrm{~nm}$. The change in DNA content was expressed as follows:

$\triangle$ DNA $(\mu \mathrm{g} / 5 \mathrm{~mm})=$ DNA in injured side $(\mu \mathrm{g} / 5 \mathrm{~mm})$

DNA in sham-operated side $(\mu \mathrm{g} / 5 \mathrm{~mm})$

\section{Drugs}

For the in vivo experiments, we chose the doses of tranilast according to the serum concentration that showed efficacy in the granuloma model of rats and in clinical use. The serum concentration of tranilast administered at the dose of $200-300 \mathrm{mg} / \mathrm{kg}$ to rabbits was nearly equal to those in rats given $100 \mathrm{mg} / \mathrm{kg}$ and humans given $600 \mathrm{mg} / \mathrm{body} / \mathrm{day}$. The doses of losartan were selected according to the report of Azuma et al. (17). Tranilast and losartan were suspended or dissolved in $0.5 \%$ carboxy methylcellulose solution and were administered perorally once a day from the day after the operation.

The serum concentration of tranilast after peroral administration at the dose of $200-300 \mathrm{mg} / \mathrm{kg}$ in rabbits is about $100 \mu \mathrm{M}$, so we used a tranilast concentration of 30 $\mu \mathrm{M}$ to $300 \mu \mathrm{M}$, which did not cause cell death, in this in vitro experiments.

\section{Cell culture}

Rabbit VSMCs were prepared by the explant method described by Ross (22). First, thoracic aortas were obtained from three rabbits. The adventitias were carefully removed, and the inner surfaces were scraped to remove endothelial cells. Then the medial explants were minced into 1-mm pieces and then cultured in DMEM supplemented with FBS $(20 \%)$, penicillin (50 units $/ \mathrm{ml}$ ), streptomycin (50 units $/ \mathrm{ml}$ ), kanamycin ( 50 units $/ \mathrm{ml}$ ) and amphotericin B $(1 \mathrm{mg} / \mathrm{ml})$. After 2-3 weeks, the cells that had migrated from the explants were removed by trypsinization and seeded into $25-\mathrm{cm}^{2}$ flasks. Confluent VSMCs at the second passage were subcultured in DMEM supplemented with 10\% FBS at a 1:5 split ratio. The identification of VSMCs was confirmed by typical morphological characteristics (spindle shape, hill and valley patterns) and indirect immunofluorescent staining with a monoclonal anti- $\alpha$-smooth muscle actin antibody (clone: 1A4; Dako Japan Co., Ltd., Kyoto) (23). VSMCs were used within 10 passages in this study. 


\section{Migration assay}

The migration of cells was assayed by a modified Boyden's chamber method using a 96-well Boyden chamber apparatus (Neuroprobe, Inc., Cabin John, MD, USA) (24). PDGF-BB $(50 \mathrm{ng} / \mathrm{ml})$ was first diluted in DMEM with or without tranilast and then loaded into the lower wells of the Boyden chamber. The wells were subsequently covered with a standard 8 -mm pore filter (Nucleopore Corp., Pleasanton, CA, USA) coated with type I collagen. Cell suspensions $\left(1 \times 10^{4}\right.$ cells $)$ in DMEM containing $0.1 \%$ bovine serum albumin (BSA) with or without tranilast were then loaded into the upper wells of the chamber, after which the chamber was incubated for $4 \mathrm{hr}$ at $37^{\circ} \mathrm{C}$ in an atmosphere of $95 \%$ air and $5 \% \mathrm{CO}_{2}$. Non-migrated cells on the upper surface were scraped off. The filters were then fixed in methanol and stained with Diff-Quick staining solution (International Reagent Corp., Kobe). The number of VSMCs per $400 \times$ highpower field (HPF) that had migrated onto the lower surface of the filters was then determined microscopically. Four HPFs were counted per well, and the values were averaged.

\section{Measurement of DNA synthesis}

Cells were grown to confluence in 96-well tissue culture dishes and the growth was arrested for $48 \mathrm{hr}$ in a serumfree medium consisting of DMEM supplemented with 5 $\mu \mathrm{g} / \mathrm{ml}$ insulin, $5 \mu \mathrm{g} / \mathrm{ml}$ transferrin and $5 \mathrm{ng} / \mathrm{ml}$ selenium (ITS). The DMEM/ITS medium was employed to maintain the VSMC in a quiescent, but not catabolic, state, a condition resembling that of healthy cells in the normal arterial wall in vivo (25). The DMEM/ITS medium was then removed, and fresh DMEM containing PDGF-BB $(50 \mathrm{ng} / \mathrm{ml})$ was added to the quiescent cells. The cells were subsequently incubated for $22 \mathrm{hr}$ in the absence or presence of tranilast. The cells were then incubated with ${ }^{3} \mathrm{H}$-thymidine $(46 \mathrm{kBq} / \mathrm{ml})$ for $2 \mathrm{hr}$ in the absence or presence of tranilast. Next, ice-cold $10 \%$ trichloroacetic acid was added to each well, and the plates were kept at $4^{\circ} \mathrm{C}$ for $10 \mathrm{~min}$. Trichloroacetic acid-insoluble materials were then harvested onto Unifilter plates (GF/B 96; Packard Instrument Company, Meriden, CT, USA) with a cell harvester. The extent of ${ }^{3} \mathrm{H}$-thymidine incorporation was determined by scintillation counting.

\section{Measurement of collagen synthesis}

Confluent cells were incubated for $6 \mathrm{hr}$ at $37^{\circ} \mathrm{C}$ in DMEM containing ascorbic acid $(100 \mu \mathrm{g} / \mathrm{ml}), \beta-$ aminopropionitrile $(100 \mu \mathrm{g} / \mathrm{ml})$, and ${ }^{3} \mathrm{H}$-proline $(74$ $\mathrm{kBq} / \mathrm{ml}$ ) with or without tranilast. Subsequently, the medium and cell layer were collected and then precipitated with $10 \%$ trichloroacetic acid and $0.5 \%$ tannic acid. After centrifugation, the pellet was washed with acetone and dissolved in $0.1 \mathrm{~N} \mathrm{NaOH}$. Collagen synthesis was then quantified by a bacterial collagenase digestion method (Clostridium histolyticum type III; Wako, Tokyo) modified from procedure of Peterkofsky and Diegelmann (26). Collagen synthesis was determined by measuring the dpm of ${ }^{3} \mathrm{H}$-proline per mg of DNA.
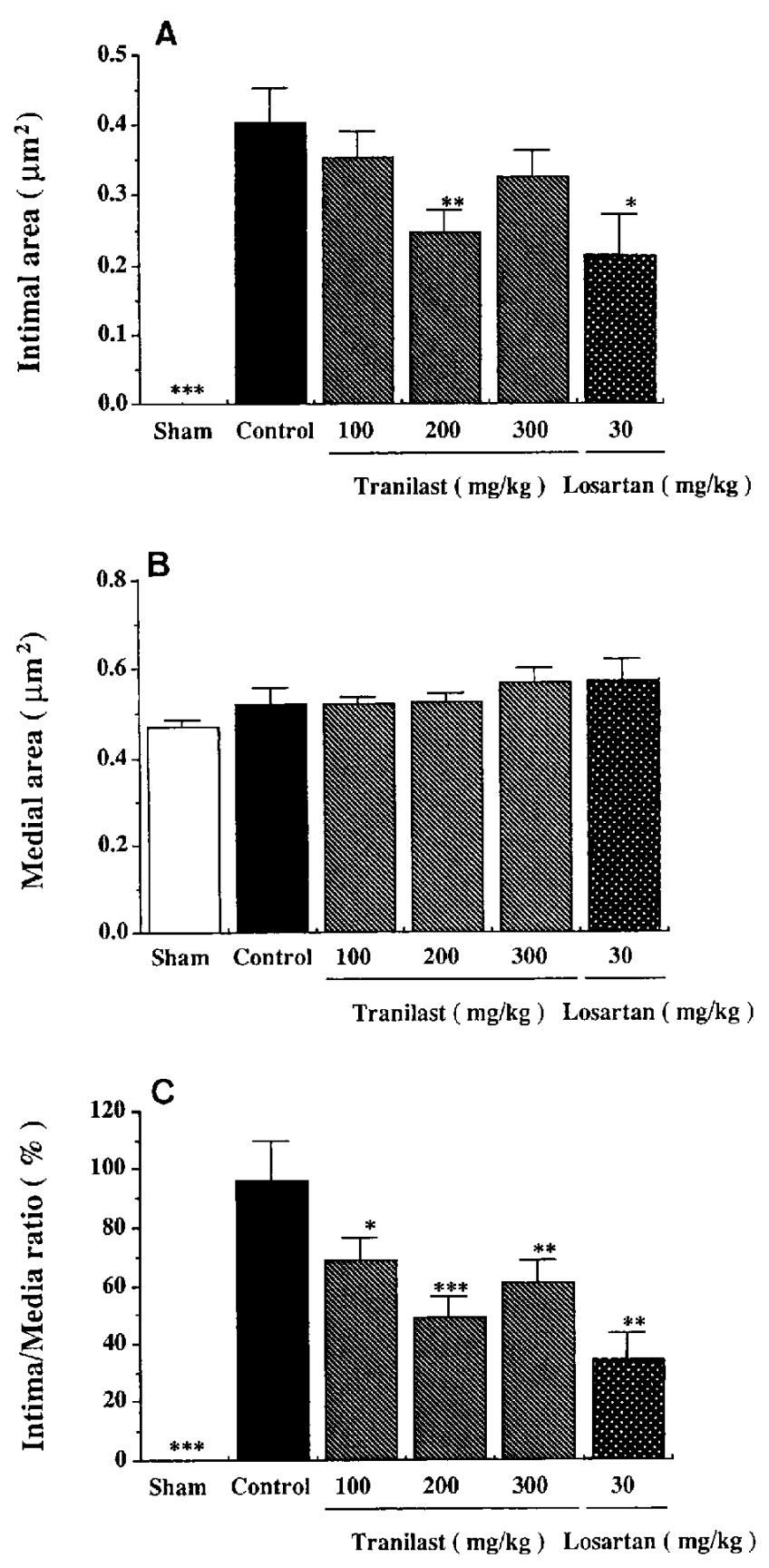

Fig. 1. Effects of tranilast and losartan on intimal area (A), medial area (B) and intima/media ratio (C) after balloon-induced endothelial denudation of carotid artery in rabbits. The arteries were examined 4 weeks after the injury. Data are each the mean \pm S.E. of 4-10 animals. ${ }^{*} * *$ and $* * *$ : Significantly different from the control at $\mathbf{P}<0.05, \mathbf{P}<0.01$ and $\mathbf{P}<0.001$, respectively. 


\section{Measurement of total protein synthesis}

Confluent cells were incubated for $6 \mathrm{hr}$ at $37^{\circ} \mathrm{C}$ in DMEM containing ${ }^{3} \mathrm{H}$-leucine $(74 \mathrm{kBq} / \mathrm{ml})$ with or without tranilast. Subsequently, the medium and cell layer were collected and then precipitated with $10 \%$ trichloroacetic acid and $0.5 \%$ tannic acid. After centrifugation, the pellet was washed with $5 \%$ trichloroacetic acid and $0.25 \%$ tannic acid, and dissolved in PBS. Total protein synthesis was determined by measuring the dpm of ${ }^{3} \mathrm{H}$-leucine per $\mu \mathrm{g}$ of DNA.

\section{Data analyses}

Statistical analyses were performed by ANOVA and Fisher's PLSD test on a Stad View 4.0 software program (Abacus Concepts, Inc., Berkley, CA, USA). Data are represented as means \pm S.E.

\section{RESULTS}

Effect of tranilast on intimal hyperplasia in balloon injury model

After vascular injury, although the medial area showed no significantly thickening, intimal hyperplasia occurred (Fig. 1: $\mathrm{A}$ and $\mathrm{B}$ ). The $\mathrm{I} / \mathrm{M}$ ratio in the control group increased to $95.9 \pm 13.8 \%$. Tranilast $(100,200$ and 300 $\mathrm{mg} / \mathrm{kg} /$ day) significantly suppressed it to $68.9 \pm 7.8 \%$, $49.0 \pm 7.1 \%$ and $60.8 \pm 8.1 \%$, respectively. Losartan (30 $\mathrm{mg} / \mathrm{kg} /$ day) also suppressed the $\mathrm{I} / \mathrm{M}$ ratio to $33.8 \pm 9.5 \%$ (Fig. 1C). The stenosis ratio in the control group also increased to $43.6 \pm 7.0 \%$. Tranilast $(200$ and 300 $\mathrm{mg} / \mathrm{kg} /$ day) and losartan $(30 \mathrm{mg} / \mathrm{kg} /$ day) significantly inhibited this ratio (Fig. 2). Furthermore, vascular DNA content in the control group increased after vascular in-

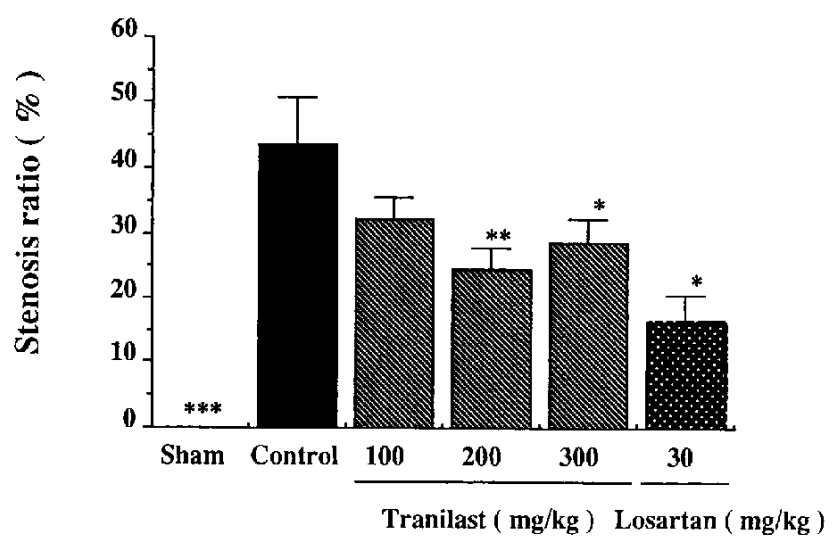

Fig. 2. Effects of tranilast and losartan on stenosis ratio after balloon-induced endothelial denudation of carotid artery in rabbits. The arteries were examined 4 weeks after the injury. Data are each the mean \pm S.E. of 4-10 animals. ${ }^{* * *}$ and ${ }^{* * *}$ : Significantly different from the control at $\mathrm{P}<0.05, \mathrm{P}<0.01$ and $\mathrm{P}<0.001$, respectively.

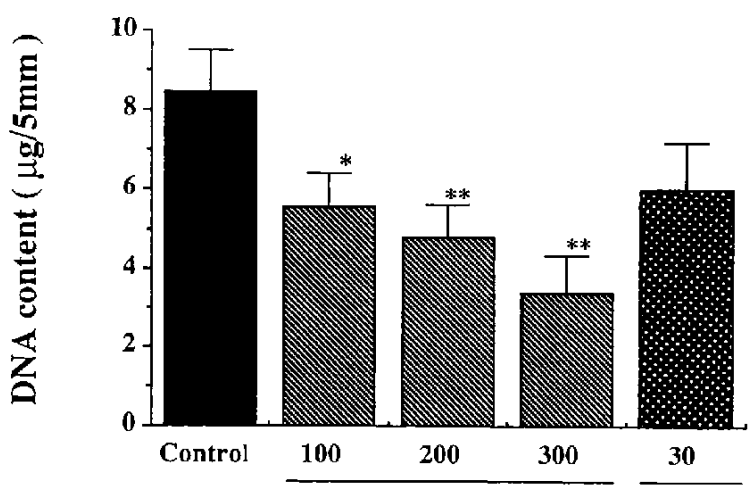

Tranilast ( $\mathrm{mg} / \mathrm{kg}) \quad$ Losartan ( $\mathrm{mg} / \mathrm{kg}$ )

Fig. 3. Effects of tranilast and losartan on the vascular DNA contents after balloon-induced endothelial denudation of carotid artery in rabbits. The arteries were removed 4 weeks after the injury and analyzed for DNA content. Data are each the mean \pm S.E. of $4-8$ animals. ${ }^{*}$ and ${ }^{* *}$ : Significantly different from the control at $\mathbf{P}<0.05$ and $\mathbf{P}<0.01$, respectively.

jury. Tranilast $(100-300 \mathrm{mg} / \mathrm{kg} /$ day $)$ inhibited dose-dependently and significantly the increase in DNA content. On the other hand, losartan showed no significant effect on the DNA content after vascular injury (Fig. 3).

\section{Effect of tranilast on intimal hyperplasia in cuff treatment model}

Intimal hyperplasia also occurred by cuff treatment. That is, the $\mathbf{I} / \mathbf{M}$ ratio in the control group increased to $19.1 \pm 2.3 \%$. Tranilast $(200$ and $300 \mathrm{mg} / \mathrm{kg} /$ day $)$ significantly inhibited the intimal hyperplasia to $10.6 \pm 1.2 \%$ and $10.3 \pm 0.7 \%$, respectively. Losartan showed no effect on intimal hyperplasia (Fig. 4).

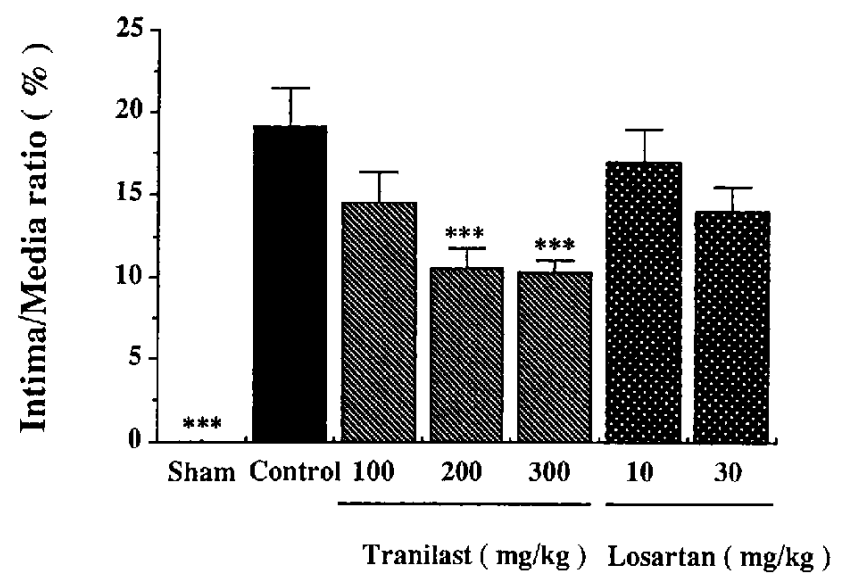

Fig. 4. Effects of tranilast and losartan on intimal/medial ratio after cuff treatment around the common carotid artery in rabbits. The arteries were examined 3 weeks after treatment. Data are each the mean \pm S.E. of $6-11$ animals. ${ }^{* * *}$ : Significantly different from the control at $\mathrm{P}<0.001$. 

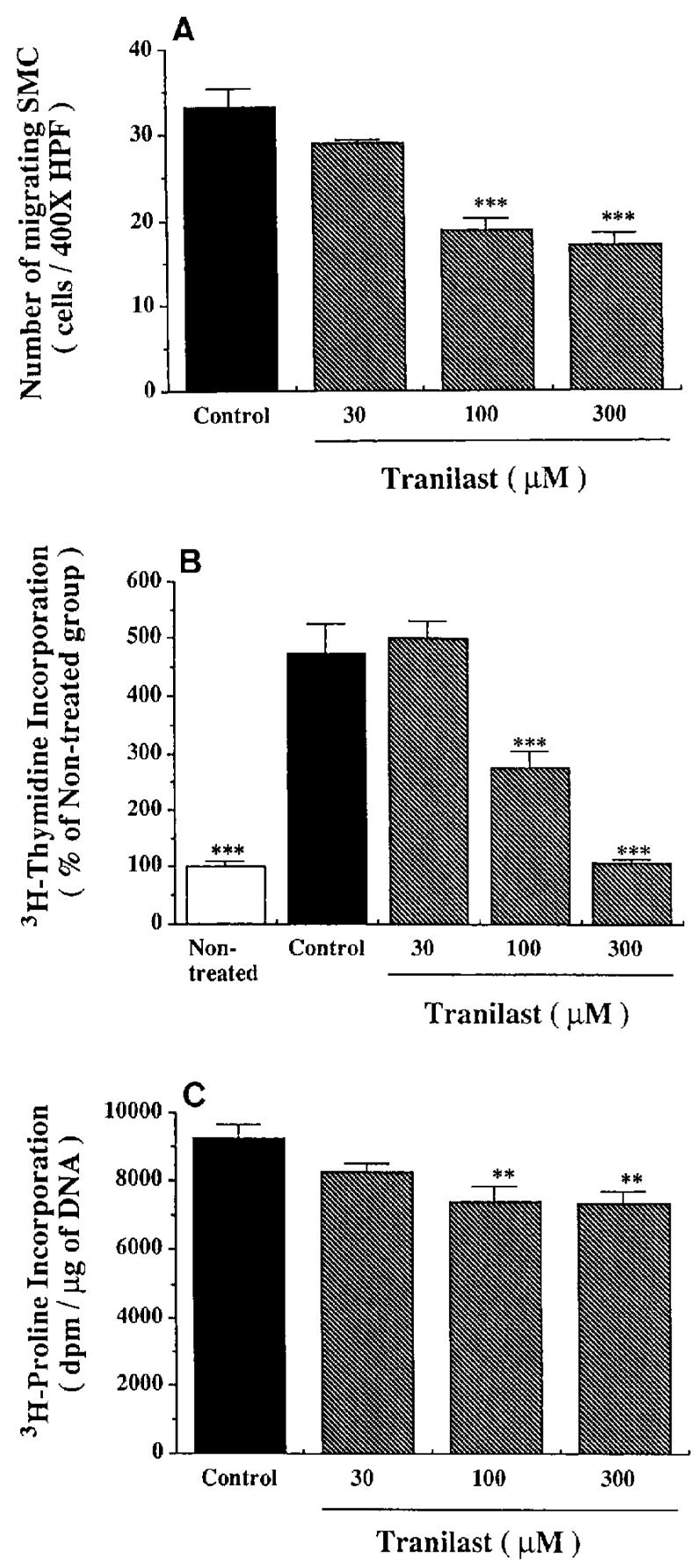

Fig. 5. Effect of tranilast on PDGF-induced VSMC migration of (A), PDGF-induced VSMC proliferation by (B) and collagen synthesis in (C) rabbit VSMCs. Concentration of PDGF was $50 \mathrm{ng} / \mathrm{ml}$. Data are each the mean \pm S.E. of 5 experiments. ${ }^{* *}$ and $* * *$ : Significantly different from the control at $\mathrm{P}<0.01$ and $\mathrm{P}<0.001$, respectively.

\section{Effect of tranilast on VSMC migration}

PDGF-BB induced VSMC migration (33.2 \pm 2.2 cells $/ 400 \times$ HPF) in the control group. Tranilast (100 and $300 \mu \mathrm{M})$ concentration-dependently and significantly decreased the number of migrating cells (Fig. 5A).

\section{Effect of tranilast on DNA synthesis}

${ }^{3} \mathrm{H}$-Thymidine incorporation was measured as a marker of DNA synthesis. ${ }^{3} \mathrm{H}$-Thymidine incorporation increased to $474.1 \pm 50.1 \%$ after stimulation by PDGF-BB in the control group. Tranilast (100 and $300 \mu \mathrm{M})$ significantly decreased ${ }^{3} \mathrm{H}$-thymidine incorporation (Fig. 5B).

\section{Effect of tranilast on collagen synthesis and total protein synthesis}

${ }^{3} \mathrm{H}$-Proline incorporation was measured as a marker of collagen synthesis. Tranilast $(100$ and $300 \mu \mathrm{M})$ concentration-dependently and significantly inhibited the ${ }^{3} \mathrm{H}$ proline incorporation by VSMCs (Fig. 5C). On the other hand, tranilast had no effect on total protein synthesis by VSMCs (data not shown).

\section{DISCUSSION}

Animal models of vascular intimal hyperplasia are separable into two categories: the first is intraluminal manipulation such as in vascular endothelial denudation using a balloon catheter, and the second is perivascular manipulation such as in positioning a cuff around an artery (27). In the intraluminal manipulation model, platelets aggregate and leukocytes accumulate on the endothelial denudated area, where they release cytokines (4, 28 ). These cytokines induce VSMC migration from the media to the intima and VSMC proliferation there. The VSMCs that have migrated and proliferated not only release cytokines, which make other VSMCs migrate and proliferate, but also produce an extracellular matrix $(2-4)$. The precise mechanism of intimal hyperplasia in the perivascular manipulation model is yet unknown; However, it is reported that leukocytes accumulate in the intima of the perivascularly manipulated area, where their products cause endothelial denudation $(20,27)$. After endothelial loss, intimal hyperplasia then occurs by the same mechanism as in the intraluminal manipulation model.

In this study, we investigated the effect of tranilast on intimal hyperplasia in both intraluminal manipulation and perivascular manipulation models, i.e., in the balloon injury model and the cuff treatment model, respectively. In both animal models, intimal hyperplasia occurred and tranilast suppressed it. Moreover, in the balloon injury model, tranilast inhibited the increase in vascular DNA content, whose increase may indicate VSMC migration and/or proliferation. These results suggested that tranilast suppresses the intimal hyperplasia after vascular injury.

On the other hand, losartan suppressed the intimal hyperplasia in the balloon injury model, like tranilast. However, losartan had no effect on the intimal hyper- 
plasia in the cuff treatment model, although tranilast suppressed it. In the cuff treatment model, the leukocytes accumulated in the intima play an important role in endothelial denudation via the inflammatory response, including the production of oxygen radicals (20). Tranilast is reported to prevent the inflammatory response and production of oxygen radicals (11). On the other hand, losartan is an Ang II antagonist, and it may be ineffective to prevent inflammation. Because of these reasons, we speculated that the difference of the effects of tranilast and losartan in the cuff treatment model is due to the effect on the inflammatory responses. In addition, it is reported that tranilast has an Ang II-receptor antagonistic effect; however, the $\mathrm{IC}_{50}$ of tranilast is about $1 / 1000$ that of losartan (29). From these things, we thought that tranilast shows the suppressive effect on the intimal hyperplasia via the different mechanisms from losartan.

Tranilast had no effect on platelet aggregation (data not shown). So, the effect of tranilast on intimal hyperplasia depends on the inhibition of the pathway subsequent to platelet aggregation. Previous studies suggested that some cytokines, such as PDGF, released from vascular endothelial cells, aggregated platelets and VSMCs, play an important role in the development of intimal hyperplasia (4-6). Because of these findings, we investigated the effects of tranilast on the PDGF-induced VSMC migration and proliferation. Also, we observed the VSMC synthesis of collagen, a protein component of the extracellular matrix, because it is reported that the accumulation of collagen produced by VSMCs is one of the causes of the intimal hyperplasia $(2,28)$. In this study, tranilast inhibited both PDGF-induced VSMC migration and proliferation. Moreover, tranilast inhibited collagen synthesis by VSMCs but not total protein synthesis, suggesting a specific effect on collagen synthesis. Thus tranilast prevents VSMC migration and proliferation, and accumulation of the extracellular matrix.

From the findings in this study, we conclude that tranilast manifests its suppressive effect on intimal hyperplasia after vascular injury by preventing VSMC migration from the media to the intima, VSMC proliferation in the intima, and accumulaton of the extracellular matrix produced by the VSMCs. Recently, it was reported that tranilast suppressed intimal hyperplasia in photochemically-induced intimal hyperplasia in spontaneously hypertensive rats (30). These results suggest that tranilast is useful for preventing restenosis after PTCA.

\section{Acknowledgments}

We thank Tuyoshi Kitamura, Morimichi Hayashi and Tatsuya Nagasawa in the Second Laboratories of Kissei Phamaceutical Co., Ltd. for supporting our investigation.

\section{REFERENCES}

1 Scheinowitz M, Shou M, Banai S, Gertz SD, Lazarous DF and Unger EF: Neointimal proliferation in canine coronary arteries. A model of restenosis and continuous drug delivery. Lab Invest 71, 813-819 (1994)

2 Strauss BH, Chisholm RJ, Keely FW, Gotlieb AI, Logan RA and Armstrong PW: Extracellular matrix remodeling after balloon angioplasty injury in an rabbit model of restenosis. Circ Res 75, 650-658 (1994)

3 Mitsuka $\mathrm{M}$, Nagae $\mathrm{M}$ and Berk $\mathrm{BC}: \mathrm{Na}^{+}-\mathrm{H}^{+}$exchanger inhibitors decrease neointimal formation after rat carotid injury. Effects on smooth muscle cell migration and proliferation. Circ Res 73, 269-275 (1993)

4 Ross R: The pathogenesis of atherosclerosis: a perspective for the 1990s. Nature 362, $801-808$ (1993)

5 Simons M, Edelman ER, Haimovitz-Friedmann A, Vergilio J and Nicholson AC: Antisense proliferating cell nuclear antigen oligonucleotides inhibit intimal hyperplasia in a rat carotid arterial injury model. J Clin Invest 93, 2351-2356 (1994)

6 Mogami $\mathrm{H}$ and Kojima I: Stimulation of calcium entry is prerequisite for DNA synthesis induced by platelet-derived growth factor in vascular smooth muscle cells. Biochem Biophys Res Commun 29, 650-658 (1993)

7 Koda A, Nagai H, Watanabe S, Yanagihara $Y$ and Sakamoto K: Inhibition of hypersensitivity reactions by a new drug, $N$ (3',4'-dimethoxycinnamoyl) anthranilic acid (N-5). J Allergy Clin Immunol 57, 396-407 (1976)

8 Komatsu H, Kojima M, Tsutsumi N, Hamano S, Kusama H, Ujiie A, Ikeda S and Nakazawa M: Study of the mechanism of inhibitory action of tranilast on chemical mediator release. Jpn J Pharmacol 46, 43-51 (1988)

9 Suzawa $H$, Kikuchi S, Ichikawa $\mathbf{K}$ and Koda A: Inhibitory action of tranilast, an anti-allergic drug, on the release of cytokines and $\mathrm{PGE}_{2}$ from human monocytes-macrophages. Jpn J Pharmacol 60, 85-90 (1992)

10 Suzawa H, Kikuchi S, Arai N and Koda A: The mechanism involved in the inhibitory action of tranilast on collagen biosynthesis of keloid fibroblasts. Jpn J Pharmacol 60, 91 -96 (1992)

11 Suzawa H, Ichikawa K, Kikuchi S, Yamada K, Tsuchiya O, Hamano S, Komatsu $\mathrm{H}$ and Miyata $\mathrm{H}$ : Effect of tranilast, an anti-allergic drug, on carrageenin-induced granulation and capillary permeability in rats. Folia Pharmacol Jpn 99, 241 - 246 (1992) (Abstr in English)

12 Suzawa H, Kikuchi S, Ichikawa K, Arai N, Tazawa S, Tuchiya O, Momose Y, Shibata N, Sugimoto C, Hamano S, Komatsu H and Miyata $\mathrm{H}$; Effect of tranilast, an anti-allergic drug, on the human keloid tissue. Folia Pharmacol Jpn 99, 231 - 239 (1992) (Abstr in English)

13 Viswanathan M, Strömberg C, Seltzer A and Saavedra JM: Balloon angioplasty enhances the expression of angiotensin II $\mathrm{AT}_{1}$ receptors in neointima of rat aorta. J Clin Invest $\mathbf{9 0}$, $1707-1712$ (1992)

14 Daemen MJAP, Lombardi DM, Bosman FT and Schwartz SM: Angiotensin II induces smooth muscle cell proliferation in the normal and injured rat arterial wall. Circ Res 68, 450-456 (1991)

15 Osterrieder W, Müller RKM, Powell JS, Clozel JP, Hefti F and Baumgartner HR: Role of angiotensin II in injury-induced neointima formation in rats. Hypertension 18, Supp II, 60-64 
(1991)

16 Clozel JP, Hess P, Micael C, Schietinger K and Baumgartner HR: Inhibition of converting enzyme and neointima formation after vascular injury in rabbits and guinea pigs. Hypertension 18, Supp II, 55-59 (1991)

17 Azuma $H$, Niimi $Y$ and Hamasaki H: Prevention of intimal thickening after endothelial removal by a nonpeptide angiotensin II receptor antagonist, losartan. Br J Pharmacol 106, $665-671$ (1992)

18 Kawamura M, Terashita Z, Okuda H, Imura Y, Shino A, Nakao $M$ and Nishikawa K: TCV-116, a novel angiotensin II receptor antagonist, prevents intimal thickening and impairment of vascular function after carotid injury in rats. J Pharmacol Exp Ther 266, 1664-1669 (1993)

19 Kauffman RF, Bean JS, Zimmerman KM, Brown RF and Steinberg MI: Losartan, a nonpeptide angiotensin II (ANG II) receptor antagonist, inhibits neointima formation following balloon injury to rat carotid arteries. Life Sci 49, PL223-PL228 (1991)

20 Hirosumi L, Nomoto A, Ohkubo Y, Sekiguchi C, Mutoh S, Yamaguchi $I$ and Aoki $\mathrm{H}$ : Infammatory responses in cuffinduced atherosclerosis in rabbits. Atherosclerosis 64, 243-254 (1987)

21 Lobarca C and Paigen K: A simple, rapid and sensitive DNA assay procedure. Anal Biochem 102, 344-352 (1980)

22 Ross R: The smooth muscle II. Growth of smooth muscle in culture and formation of elastic fibers. J Cell Biol 50, 172 (1971)

23 Skalli $O$, Ropraz P, Trzeciak A, Benzonana G, Gillessen D and
Gabbian G: A monoclonal antibody against $\alpha$-smooth muscle actin: A new probe for smooth muscle differentiation. J Cell Biol 103, 2787-2796 (1986)

24 Grotendorst GR, Chang T, Seppa HEJ, Kleinman HK and Martin GR: Platelet-derived growth factor is a chemoattractant for vascular smooth muscle cells. J Cell Physiol 113, 261-266 (1982)

25 Libby P and O'Brien KV: Culture of quiescent arterial smooth muscle cells in a defined serum-free medium. J Cell Physiol 115, 217-223 (1983)

26 Peterkofsky B and Diegelmann R: Use of a mixture of proteinfree collagenase for the specific assay of radioactive collagen in the presence of the proteins. Biochemistry 10, 988-999 (1971)

27 Kockx MM, De Meyer GRY, Jacob WA, Bult H and Herman AG: Triphasic sequence of neointimal formation in the cuffed carotid artery of the rabbit. Arteriol Thromb 12, 1447-1457 (1992)

28 Tanaka H, Sukhova GK, Swanson SJ, Clinton SK, Granz P, Cybulsky ML and Libby P: Sustained activation of vascular cells and leucocytes in the rabbit aorta after balloon injury. Circulation 88 [part 1], 1788-1803 (1993)

29 Miyazawa K, Fukuyama J, Misawa K, Hamano S and Ujiie A: Tranilast antagonizes angiotensin II and its biological effects in vascular smooth muscle cells. Atheroscrelosis (in press)

30 Kikuchi S, Umemura K, Kondo K and Nakashima M: Tranilast suppresses intimal hyperplasia after photochemically-induced endothelial injury in the rat. Eur J Pharmacol 295, 221-227 (1996) 